\title{
Dampak COVID-19 Terhadap Permintan Susu Kambing Peranakan Etawa di Desa Aikmual Lombok Tengah
}

\author{
(The impact of COVID-19 on the demand for Ettawa's Crossbreed Goat Milk in \\ the Village of Aikmual, Central Lombok)
}

\author{
Rosiadi, Alfiana Laili Dwi Agustin, Chandra Dwi Atma dan Novarina Sulsia Ista'in Ningtyas \\ Fakultas Kedokteran Hewan Universitas Pendidikan Mandalika \\ Email : rosadikun@gmail.com
}

Diterima : 20 September 2020/Disetujui : 02 Januari 2021

\begin{abstract}
ABSTRAK
Susu kambing Peranakan Etawa merupakan salah satu alternatif yang dipilih oleh masyarakat sebagai pengganti susu sapi. Masyarakat di Indonesia meyakini susu dapat meningkatkan antibodi. Penelitian ini bertujuan untuk mengetahui apakah permintan susu kambing meningkat atau menurun pada saat adanya COVID-19. Penelitian ini dilakukan pada bulan Mei 2020 dan menggunakan metode deskriftif berbasis kuisioner, Sampel berjumlah 5 peternak kambing peranakan etawa. Komunikasi untuk melakukan proses wawancara dilakukan via handphone. Data di analisis menggunakan uji Break Event point (BEP). Hasil studi menunjukkan bahwa pada saat adanya pandemi COVID-19 permintan susu kambing peranakan eatawa meningkat. Adanya pandemi ini memberi dampak yang positif dilihat dari permintan konsumen yang tidak turun, dan meningkatnya permintan susu yang semulanya dalam satu bulan terjual 50 liter menjadi 75 liter setelah adanya pandemik.
\end{abstract}

Kata Kunci : BEP (Break event point), COVID-19, Susu Kambing Peranakan Etawa.

\begin{abstract}
Ettawa's crossbreed goat milk is one of the alternatives chosen by the community as a substitute for cow's milk. People in Indonesia believe that milk may increase antibodies. This study aimed to find out whether the demand for goat's milk increases or decreases during the presence of COVID-19. This study was carried out in May 2020 and used a questionnaire-based descriptive method. The sample consisted of 5 breeders of Ettawa crossbred goats. Communication to complete the interview process was conducted via cellphone. Data obtained was then analyzed using the Break Event point (BEP) test. The results show that during the COVID-19 pandemic the demand for Ettawa's crossbreed goat milk increased. The existence of this pandemic has had a positive impact which can be seen from consumer demand that has not decreased, and the increase in demand for milk which was originally sold 50 liters in one month to 75 liters after the pandemic.
\end{abstract}

Keywords: BEP (Break event point), COVID-19, Ettawa's crossbreed goat milk. 


\section{PENDAHULUAN}

Susu kambing Peranakan Etawa merupakan salah satu alternatif yang dipilih oleh masyarakat sebagai pengganti susu sapi (Mulyono dan Sarwono, 2008), masyarakat di Indonesia meyakini susu kambing memiliki banyak khasiat seperti pengobatan saluran pencernaan seperti menceret serta alergi oleh susu sapi, meningkatkan antibodi, tingkat kecernaan yang tinggi, alergenisitas yang rendah dan komposisi kimia bermanfaat, lebih mirip dengan susu manusia dibandingkan susu sapi (Ratya dkk, 2017; Purnomoa dkk, 2006). Hasil wawancara pada peternakan kambing Etawa di desa Aikmual Lombok Tengah yang dilakukan sebelum adanya pandemic Corona virus disease 2019 (COVID19) menunjunkan bahwa minat masyarakat di pulau Lombok terhadap susu Peranakan Etawa cukup tinggi, adanya pandemi COVID-19 menurut Burhanudin dan Abdi (2020) tidak hanya mempengaruhi kesehatan masyarakat tetapi juga mempengaruhi perekonomian negara.

Corona virus disease 2019 menjadi perhatian bagi banyak orang, sampai saat ini data dari pemerintah Indonesia menunjukan bahwa masyarakat yang positif COVID-19 mencapai 18.000 kasus (World Health Organization, 2020). Menurut McNamara et al (2020) COVID-19 diisukan dapat berada di peternakan dan peternakan unggas. COVID-19 merupakan virus zoonosis, hasil penelitian pada kucing dan anjing yang hidup dekat bersama pasien yang menderita COVID-19 menunjukan bahawa virus tersebut dapat terdeteksi di trakea, paru-paru dan usus kecil (Shi et al., 2020). Hal tersebut akan berdampak pula pada permintaan susu Kambing Peranakan Eatawa, yang nantinya akan berakibat pada perekonomian peternak bahkan dapat berdampak pada kesehatan ternak.

Adanya himbauan dari pemerintah untuk melakukan aktifitas di rumah saja berdampak pada berbagai sector termasuk pada sector peternakan, pembatasan lalu lintas dan mobilitas dari kendaraan membuat peternak akan merasakan dampak dari hal tersebut.

\section{METODE}

Penelitian ini menggunakan kuisioner kepada peternak Kambing Peranakan Etawa sebagai objek penelitian. Peternak berjumlah 5 orang. Penelitian ini dilakukan pada bulan mei 2020 di Desa Aikmual Kabupaten Lombok Tengah. 
Jenis Penelitian ini menggunaka metode deskriftif berbasis kuisioner untuk mendapatkan data tentang apakah pandemi COVID-19 ini berdampak pada permintan. Melakukan komunikasi via handphone untuk melakukan kuisioner kepada 5 peternak untuk mengetahui dampak COVID-19 terhadap permintan susu. Data yang diperoleh kemudian dianalisis dengan uji BEP

\section{HASIL}

Berdasarkan hasil wawancara dengan peternak dikethui rata-rata jumlah susu yang terjual sebelum pandemi adalah $50.000 \mathrm{ml}$ sedangkan jumlah susu yang terjual pada saat pandemi adalah $75.000 \mathrm{ml}$, jumlah susu yang terjual pada saat pandemi meningkat.

Tabel 1. Hasil rata-rata biaya tetap dalam waktu per tahun

\begin{tabular}{llcc}
\hline No & Jenis Biaya Tetap & $\begin{array}{c}\text { Rata-rata Total Biaya/Tahun } \\
\text { (Rp.) }\end{array}$ & $\begin{array}{c}\text { Biaya Perbulan } \\
\text { (Rp.) }\end{array}$ \\
\hline 1. & Lahan & 2.600 .000 & 216.666 \\
2. & Bibit kambing & 3.800 .000 & 316.667 \\
3. & Peralatan kandang & 138.754 & 115.621 \\
4. & Listrik & 230.000 & 19.166 \\
5. & Obat & 260.000 & 21.666 \\
6. & Bensin & 160.000 & 13.333 \\
\hline \multicolumn{2}{r}{ Total } & & $\mathbf{7 0 3 . 1 1 9}$ \\
\hline
\end{tabular}

Tabel 2. Hasil rata-rata biaya variabel dalam waktu per bulan

\begin{tabular}{clc}
\hline No & Klasifikasi & Biaya per tahun (Rp.) \\
\hline 1. & Pakan hijauan & 508.000 \\
2. & Pakan konsentrat & 1.300 .000 \\
\hline & Total & $\mathbf{1 . 8 0 8 . 0 0 0}$ \\
\hline
\end{tabular}

\section{Berdasarkan hasil rata-rata} biaya tetap dan biaya variabel di atas, maka dapat diketahui biaya total sebesar:

Biaya total = biaya tetap + biaya variabel

$$
\begin{aligned}
& =\operatorname{Rp} 703.119+ \\
& \operatorname{Rp} 1.808 .000 \\
& =\operatorname{Rp} 2.511 .119
\end{aligned}
$$

Break Event Point dari peternak diperoleh sebelum adanya pandemi sebagai berikut:

Rata-rata harga jual susu (P) per bulan $=8.000$ Rupiah/Liter $\mathrm{x} 50=\mathrm{Rp}$ 400.000

Rata-rata jumlah susu yang terjual (Q) per bulan $=50.000 \mathrm{ml}=50 \mathrm{~L}$ 


$$
\begin{array}{ll}
\mathrm{BEP} \text { produksi }=\mathrm{TC} / \mathrm{P} & \mathrm{BEP} \text { harga }=\mathrm{TC} / \mathrm{Q} \\
=\mathrm{Rp} 2.511 .119 / 400.000 & =\mathrm{Rp} 2.511 .119 / 50 \\
=6,27 \mathrm{Liter} & =\mathrm{Rp} 50.222
\end{array}
$$

Dimana:

$\mathrm{TC}=$ Total Cost (biaya total)

$\mathrm{P}=$ Price atau Harga (rupiah/liter)

$\mathrm{Q}=$ Produksi (liter)

Break Event Point dari peternak diperoleh setelah adanya pandemi sebagai berikut:

Rata-rata harga jual susu (P) per bulan $=8.000$ Rupiah $\times 75=\operatorname{Rp} 600.000$

Rata-rata jumlah susu yang terjual

(Q) per bulan $=75.000 \mathrm{ml}=75 \mathrm{~L}$

$$
\begin{array}{ll}
\text { BEP produksi }=\mathrm{TC} / \mathrm{P} & \text { BEP Harga }=\mathrm{TC} / \mathrm{Q} \\
=\mathrm{Rp} 2.511 .119 / 600.000 & =\mathrm{Rp} 2.511 .119 / 75 \mathrm{~L} \\
=4,18 \text { Liter } & =\mathrm{Rp} 33.481
\end{array}
$$

Dimana:

$\mathrm{TC}=$ Total Cost (biaya total)

b. Jika BEP harga = Jumlah harga, maka usaha berada pada posisi titik impas atau tidak laba/tidak rugi.
$\mathrm{P}=$ Price atau Harga (rupiah/ ekor)
$\mathrm{Q}=$ Produksi (ekor)

Kriteria BEP Produksi adalah sebagai berikut :

a) Jika BEP Produksi < Jumlah Produksi, maka usaha berada pada posisi menguntungkan.

b) Jika BEP Produksi = Jumlah Produksi, maka usaha berada pada posisi titik impas atau tidak laba/tidak rugi.

c) Jika BEP Produksi $>$ Jumlah Produksi maka usaha berada pada posisi yang tidak menguntungkan.

Kriteria BEP harga adalah sebagai berikut:

a. Jika BEP harga < Jumlah harga, maka usaha berada pada posisi menguntungkan.

c. Jika BEP harga $>$ Jumlah hargamaka usaha berada pada posisi yang tidak menguntungkan.

Tabel 3. tabel titik impas/BEP produksi sebelum dan sesudah adanya pandemi

\begin{tabular}{cccccc}
\hline \multirow{2}{*}{ No } & \multirow{2}{*}{ Klasifikasi } & $\begin{array}{c}\text { Total Harga } \\
\text { (TC) }\end{array}$ & $\begin{array}{c}\text { Harga } \\
(\mathbf{P})\end{array}$ & $\begin{array}{c}\text { Jumlah Produksi/bulan } \\
(\mathbf{Q})\end{array}$ & $\begin{array}{c}\text { BEP Produksi } \\
\text { (TC/P) }\end{array}$ \\
\hline 1 & Sebelum pandemi & 2.511 .119 & 400.000 & 50 & 6,27 \\
2 & Sesudah pandemi & 2.511 .119 & 600.000 & 75 & 4,18 \\
\hline
\end{tabular}

Berdasarkan hasil perhitungan Break-even point sebelum pandemi diperoleh titk impas produksi akan tercapai jika produksi sebesar 6,27 liter, hal ini menandakan bahwa BEP Produksi sebelum adanya pandemi <
Jumlah Produksi, maka usaha berada pada posisi menguntungkan. BEP produkasi saat adanya pandemi akan mencapai titk impas jika jumlah produksi sebesar 4,18 liter, hal ini menandakan bahwa BEP Produksi < 
Jumlah Produksi, maka usaha berada

pada posisi menguntungkan.

Tabel 4. tabel titik impas/BEP harga sebelum dan sesudah adanya pandemi

\begin{tabular}{cccccc}
\hline No & Klasifikasi & $\begin{array}{c}\text { Total Harga } \\
\text { (TC) }\end{array}$ & $\begin{array}{c}\text { Jumlah Produksi/Bulan } \\
(\mathbf{Q})\end{array}$ & $\begin{array}{c}\text { Harga } \\
(\mathbf{P})\end{array}$ & $\begin{array}{c}\text { BEP Harga } \\
\text { (TC/Q) }\end{array}$ \\
\hline 1 & Sebelum pandemi & 2.511 .119 & 6,27 & 400.000 & 50.222 \\
2 & Sesudah pandemi & 2.511 .119 & 4,18 & 600.000 & 33.481 \\
\hline
\end{tabular}

Berdasarkan hasil perhitungan

Break-even point sebelum pandemi diperoleh nilai BEP harga akan mencapai titik impas jika harga tiap liternya sebesar $\mathrm{Rp}$ 50.213, hal ini menandakan bahwa BEP harga < Jumlah harga, maka usaha berada pada posisi menguntungkan, sedangan BEP harga saat adanya pandemi akan mencapai titk impas jika tiap liter susu dijual dengan harga Rp 33.475, hal ini menandakan bahwa BEP harga < Jumlah harga, maka usaha berada pada posisi menguntungkan.

\section{PEMBAHASAN}

Permintaan susu kambing sebelum adanya pandemi COVID-19 sebesar $50 \mathrm{~L} /$ bulan dan saat adanya pandemi sebesar $75 \mathrm{~L} /$ bulan yang habis terjual, saat adanya pandemi COVID-19 permintan susu kambing peranakan etawa meningkat sebesar $50 \%$ dari bulan-bulan sebelum adanya pandemi COVID-19. Penghitungan BEP (Break event point) menunjukan bahwa usaha peternakan kambing peranakan etawa ini bagus untuk dikembangkan, hasil perhitungan BEP produksi dari sebelum adanya covid dan saat adanya covid menunjukan bahwa jumlah produksi berada pada titik yang menguntungkan, dimana jumlah produksi tiap bulan melebihi BEP produksi, hal tersebut menandakan produksi dari susu kambing peranakan etawa masih dapat menutupi biaya yang dikeluarkan untuk produksi tiap liternya. Hasil untuk BEP harga sebelum dan saat adanya pandemi menunjukan bahwa harga jual lebih tinggi dari pada BEP harga, hal tersebut menandakan bahwa harga jual tiap liter air susu masih dalam kondisi baik, sehingga dapat dikatakan bahwa usaha penjualan susu peranakan etawa berada pada posisi yang menguntungkan.

Break event point merupakan suatu keadaan di mana suatu usaha tidak memperoleh laba dan tidak 
menderita rugi (penghasilan sama dengan total biaya) (Darmajati, 2008). Menurut Fuad (2002), analisis titik impas atau break-even point adalah suatu titik kembali modal dimana pengurangan penerimaan total sama dengan nol. Suatu perusahaan dikatakan dalam keadaan impas (break-even), yaitu apabila setelah disusun laporan perhitungan labarugi untuk suatu periode tertentu. Hasil penjualan (sales revenue) yang diperoleh untuk periode tertentu sama besarnya dengan keseluruhan biaya (total cost), yang telah dikorbankan sehingga perusahaan tidak memperoleh keuntungan atau menderita kerugian.

Permintan susu kambing peranakan etawa ini meningkat pada saat adanya pandemi COVID-19 dikarenakan susu kambing peranakan etawa diyakini dapat meningkatkan antibodi. Kandungan dalam susu kambing yang dapat meningkatkan antibodi adalah lemak (Budiana dan Susanto, 2005; Aliaga et., al, 2003).

Lemak adalah salah satu komponen makanan multifungsi yang sangat penting untuk kehidupan. Selain mempunyai sisi postif, lemak mempunyai sisi negtif terhadap kesehatan. Fungsi lemak terhadap tubuh antara lain sebagai sumber energi, bagian dari memberan sel, isolator dalam menjaga keseimbangan suhu tubuh, mediator aktivitas biologis antar sel, pelindung orgn tubuh, pelarut vitamin, asam lemak berperan penting dalam transport dan metabolisme lemak, fungsi imun, mempertahankan fungsi dan integritas membrane sel (Saleh, 2004).

\section{KESIMPULAN}

Kesimpulan dari penelitian ini adalah adanya pandemi ini memberi dampak yang positif dilihat dari permintan konsumen yang tidak turun, dan meningkatnya permintan susu yang semulanya dalam satu bulan terjual 50L menjadi $75 \mathrm{~L}$ setelah adanya pandemi.

\section{KONFLIK KEPENTINGAN}

Rosadi adalah mahasiswa yang sedang menyelsaikan skripsi di Fakultas Kedokteran Hewan Universitas Pendidikan Mandalika. Penelitian ini dilakukan dalam rangka menyelsaikan skripsi sebagai syarat kelulusan S1 di Fakultas Kedokteran Hewan Universitas Pendidikan Mandalika.

\section{UCAPAN TERIMA KASIH}

Terimakasih kepada peternak yang sudah membantu dalam penlitian ini 


\section{DAFTAR PUSTAKA}

Aliaga, I. L., M. J. M. Alferez, M. Barrionuevo, T. Nestares, M. R. S. Sampelayo, and M. S. Campos. 2003. Study of nutritive utilization of protein and magnesium in rats with resection of the distal small intestine. Beneficial effect of goat milk. J. Dairy Science. 86: 2968 -- 2966.

Budiana, N.S dan Susanto, D. 2005. Susu Kambing. Penebar Swadaya. Jakarta.

Burhanudin, C. I., dan M. N. Abdi. 2020. Ancaman Krisis Ekonomi Global Dari Dampak Penyebaran Virus Corona (COVID-19). Akmen. 17(1):710-718.

Darmajati. 2008. Studi Ternak Produktif. Penebar Swadaya. Jakarta.

Fuad, M, 2002, pengantar bisnis, jakarta: PT.Gramedia Pustaka Utama.

McNamara, T., Richt, J.A., Glickman, L. 2020. A Critical Needs Assessment for Research in Companion Animals and Livestock Following the Pandemic of COVID-19 in Humans. Vector Borne and Zoonotc Disease.
Mulyono dan Sarwono. 2008. Spesifikasi Kambing Peranakan Ettawah dalam Pemeliharaan di Lingkungan yang Berbeda. Program Penyuluh Peternakan. Dinas Peternakan Jawa Timur. Jawa Timur.

Purnomoa A, Hartatik, Khusnan, Salasia SIO, Soegiyono. 2006. Isolasi dan karakterisasi Staphylococcus aureus asal susu kambing Peranakan Ettawa. Media Kedokteran Hewan 22:142 147.

Ratya. N., E. Taufik. I., I. I. Arief. 2017. Karakteristik Kimia, Fisik dan Mikrobiologis Susu Kambing Peranakan Etawa di Bogor. Jurnal Ilmu Produksi dan Teknologi Hasil Peternakan. 05(01):23032227.

Saleh, E. 2004. Dasar Pengolahan Susu Dan Hasil Ikutan Ternak. Program Studi Produksi Ternak, Fakultas Pertanian Universitas Sumatera Utara. 
Shi, J., Wen, Z., Zhong, G., Yang, H., Wang, C., Huang, B., Liu, R., He, X., Shuai, L., Sun, Z., Zhao, Y., Liu, P., Liang, L., Ci, P., Wang, J., Zhang, A., Guan, Y., Tan, W., Wu, G., Chen, H. Bu, Z. 2020. Suspectibility of ferrets, cats, dogs, and other domesticated animals to SARS-Coronavirus 2. Science (04):07.
World Health Organization. Situation Report - 10 [Internet]. 2020 [updated 2020 January 30; cited 2020 March 15]. Available from: https://www.who.int/docs/def ault-source/ coronaviruse/situationreports/20200130-sitrep-10ncov. pdf?sfvrsn $=\mathrm{d} 0 \mathrm{~b} 2 \mathrm{e} 480 \_2$ 